\title{
Comparison of stereotactic body radiotherapy and radiofrequency ablation for early-stage non-small cell lung cancer: a systematic review and meta-analysis
}

\author{
Ran Zhang ${ }^{1,2 \#}$, Jingjing Kang ${ }^{1 \#}$, Shengxiang Ren ${ }^{2}$, Ligang Xing ${ }^{3}$, Yaping $\mathrm{Xu}^{1}$ \\ ${ }^{1}$ Department of Radiation Oncology, Shanghai Pulmonary Hospital, School of Medicine, Tongji University, Shanghai, China; ${ }^{2}$ Department of \\ Medical Oncology, Shanghai Pulmonary Hospital \& Institute of Thoracic Cancer, School of Medicine, Tongji University, Shanghai, China; \\ ${ }^{3}$ Department of Radiation Oncology, Shandong Key Laboratory of Radiation Oncology, Shandong Cancer Hospital and Institute, Shandong First \\ Medical University and Shandong Academy of Medical Sciences, Jinan, China \\ Contributions: (I) Conception and design: Y Xu, L Xing, S Ren; (II) Administrative support: Y Xu; (III) Provision of study materials or patients: R \\ Zhang, J Kang; (IV) Collection and assembly of data: R Zhang; (V) Data analysis and interpretation: R Zhang; (VI) Manuscript writing: All authors; \\ (VII) Final approval of manuscript: All authors. \\ "These authors contributed equally to this work. \\ Correspondence to: Yaping Xu. Department of Radiation Oncology, Shanghai Pulmonary Hospital, School of Medicine, Tongji University, No. 507 \\ Zhengmin Road, Shanghai, China. Email: xuyaping1207@163.com; Ligang Xing. Department of Radiation Oncology, Shandong Key Laboratory \\ of Radiation Oncology, Shandong Cancer Hospital and Institute, Shandong First Medical University and Shandong Academy of Medical Sciences, \\ Jinan, China. Email: xinglg@medmail.com.cn; Shengxiang Ren. Department of Medical Oncology, Shanghai Pulmonary Hospital \& Institute of \\ Thoracic Cancer, School of Medicine, Tongji University, No. 507, Zheng Min Road, Shanghai 200433, China. Email: harry_ren@126.com.
}

Background: Stereotactic body radiation therapy (SBRT) and radiofrequency ablation (RFA) are recommended for patients with inoperable early-stage non-small cell lung cancer (NSCLC), with both offering promising results. However, it is largely unknown which of these two treatment modalities provides superior benefits for patients. Therefore, this systematic review and meta-analysis compared clinical outcomes and safety between SBRT and RFA in patients with inoperable early-stage NSCLC.

Methods: Eligible studies published between 2001 and 2020 were obtained through a comprehensive search of the PubMed, Medline, Embase, and Cochrane Library databases. Original English-language studies on the treatment of early-stage NSCLC with SBRT or RFA were included. Local control (LC) rates, overall survival (OS) rates, and adverse events were obtained by pooled analyses.

Results: Eighty-seven SBRT studies (12,811 patients) and 18 RFA studies (1,535 patients) met the eligibility criteria. For SBRT, the LC rates (with $95 \%$ confidence intervals) at 1, 2, 3, and 5 years were $98 \%$ (97-98\%), 95\% (95-96\%), 92\% (91-93\%), and 92\% (91-93\%), respectively, which were significantly higher than those for RFA [75\% (69-82\%), 31\% (22-39\%), 67\% (58-76\%), and 41\% (30-52\%), respectively] $(\mathrm{P}<0.01)$. There were no significant differences in short-term OS between SBRT and RFA [1-year OS rate: $87 \%$ (86-88\%) versus $89 \%$ (88-91\%), P=0.07; 2-year OS rate: 71\% (69-72\%) versus 69\% (64-74\%), $\mathrm{P}=0.42]$. Regarding long-term OS, the 3 - and 5-year OS rates for SBRT were 58\% (56-59\%) and 39\% (37$40 \%)$, respectively, which were significantly $(\mathrm{P}<0.01)$ superior to those for RFA $[48 \%(45-51 \%)$ and $21 \%$ (19-23\%), respectively]. The most common complication of SBRT was radiation pneumonitis (grade $\geq 2$ ), making up $9.1 \%$ of patients treated with SBRT, while pneumothorax was the most common complication of RFA, making up $27.2 \%$ of patients treated with RFA.

Discussion: Compared with RFA, SBRT has superior LC and long-term OS rates but similar short-term OS rates. Prospective randomized trials with large sample sizes comparing the efficacy of SBRT and RFA are warranted.

Keywords: Stereotactic body radiotherapy (SBRT); radiofrequency ablation (RFA); meta-analysis 
Submitted Sep 16, 2021. Accepted for publication Jan 12, 2022.

doi: 10.21037/atm-21-6256

View this article at: https://dx.doi.org/10.21037/atm-21-6256

\section{Introduction}

Stereotactic body radiotherapy (SBRT) is a non-invasive treatment, which is generally delivered in high doses per fraction over one to five sessions (1). SBRT, also known as stereotactic ablative radiotherapy (SABR), is recommended as a standard treatment for patients with inoperable earlystage non-small cell lung cancer (NSCLC) by the latest National Comprehensive Cancer Network (NCCN) guidelines (2) (version 4.2021). The recent multicenter, single-arm, prospective phase II trial RTOG (Radiation Therapy Oncology Group) 0236 reported outstanding outcomes of SBRT, with 5-year primary local control (LC) and overall survival (OS) rates of $92.7 \%$ and $40.0 \%$, respectively $(3,4)$. Furthermore, RTOG 0915 , a randomized phase II multicenter study, demonstrated that patients with medically inoperable stage I peripheral NSCLC can achieve 5 -year primary tumor control and OS rates of $92.2 \%$ and $41.1 \%$, respectively, with a regimen of 48 Gy delivered in 4 fractions (5).

Radiofrequency ablation (RFA), a minimally invasive image-guided percutaneous ablation technique, provides another option for patients with medically inoperable NSCLC (6). RFA has been proved to be feasible and safe when given as an outpatient treatment or during a short hospital stay in a highly suitable group of patients $(7,8)$. For instance, the RAPTURE study, a prospective multicenter clinical trial, used RFA to treat 13 patients with earlystage NSCLC, and reported a 2 -year OS rate of $75 \%$ (9). Recently, a prospective multicenter Alliance study involving 51 patients with stage IA NSCLC reported an OS rate of $69.8 \%$ and a local tumor recurrence-free rate of $59.8 \%$ after 2 years of follow-up (10). In both trials, RFA was shown to have tolerable toxicities. Furthermore, a prospective multicenter phase II trial (11) published in 2018 arrived at a similar conclusion.

However, despite the majority of the above-mentioned studies on SBRT and RFA having a prospective design, their sample sizes were small. To date, few studies have performed a pooled analysis concerning the clinical outcomes and toxicities of SBRT or RFA, and detailed comparison of the two treatments is lacking $(12,13)$. Moreover, with the broad use of SBRT in patients with inoperable early-stage NSCLC (14), and the development of well-rounded techniques for SBRT and RFA, the survival outcomes of patients treated with SBRT or RFA may be getting better than before. Therefore, we conducted a systematic review and pooled analysis to compare LC, OS and toxicities between SBRT and RFA for the treatment of patients with inoperable early-stage NSCLC.

We present the following article in accordance with the PRISMA reporting checklist (available at https://atm. amegroups.com/article/view/10.21037/atm-21-6256/rc) (15).

\section{Methods}

\section{Search strategy}

A systematic search was conducted for relevant studies published between 2001 and 2020 in electronic databases including PubMed, Embase, Medline, and the Cochrane Library. The subject terms "non-small cell lung cancer/ carcinoma" or "NSCLC" was combined with the following specific terms: "stereotactic body radiation therapy", "stereotactic body radiotherapy", "stereotactic ablative radiation therapy", "stereotactic ablative radiotherapy", "stereotactic radiosurgery", "hypo-fractionated radiotherapy", "SABR", "SBRT", "radiofrequency ablation", "thermal ablation", "early stage", "stage I", "T1”, and "T2". The reference lists of the obtained studies were also checked.

\section{Selection criteria}

The inclusion criteria for studies were as follows: (I) Englishlanguage original articles published in peer-reviewed journals; (II) patients with stage I NSCLC [according to the American Joint Committee on Cancer (AJCC) cancer staging system] who were unsuitable for surgery; and (III) clinical outcomes were reported or explored on the basis of published articles. The following were excluded: (I) case reports, comments, editorials, and reviews; (II) studies with fewer than 15 patients treated with SBRT or fewer than 5 patients treated with RFA; (III) SBRT studies with fraction number $>8$ and fraction dose $\leq 8 \mathrm{~Gy}$; and (IV) studies involving patients who received other treatments, including surgery, chemotherapy, 
radiotherapy, and immunotherapy.

Articles were independently screened and then selected by two reviewers. In cases of studies overlapping, only the study with the most comprehensive data was selected when the patient populations were from the same institution, based on consensus between the two reviewers. However, if the patient populations were from a different period or received different regimens, all the related studies were included for analysis. If differences in opinion between the two reviewers needed to be resolved, a third reviewer (YP $\mathrm{Xu})$ was consulted.

\section{Data extraction}

Relevant characteristics were extracted from each individual study, including the first author's name, publication year, country, study design, sample size, study participant age, study participant sex (the percentage of males), stage, and follow-up period. The information was independently extracted from the included studies by two reviewers. For SBRT studies, the radiation regimen, total dose, dose per fraction, number of fractions, and biologically effective dose (BED) were also extracted, and are displayed in Table 1. The BED was calculated using the equation: $\mathrm{BED}=n d \times[1+d /$ $(\alpha / \beta)]$, in which $d$ and $n$ stand for the dose per fraction and number of fractions, respectively. The numerical value of $\alpha /$ $\beta$ was 10 (100). Regarding clinical outcomes, the 1-, 2-, 3-, and 5-year LC and OS rates were also obtained. The LC rate was calculated based on freedom from local progression. Several studies did not report survival outcomes directly but included Kaplan-Meier survival curves, so the survival outcomes were extracted from these survival curves. During this analysis, we did not attempt to obtain missing data by contacting the studies' authors. Due to the occurrence of severe adverse effects (AEs) being infrequent for both SBRT and RFA, we only included common and grade 3-5 events on the basis of the Common Terminology Criteria for Adverse Events (CTCAE). We also estimated 95\% confidence intervals (CIs) and proportions.

\section{Statistical analysis}

Both random effects and fixed effects models were used to conduct pooled analysis of the LC and OS rates for SBRT and RFA. The $\mathrm{I}^{2}$ statistic was used to measure the degree of heterogeneity caused by variability in the true effect size. Statistical analysis was performed using the SPSS software (version 22.0, IBM Corp.) and R software (version 4.0.3;
http://www.Rproject.org). Meta-analysis was conducted using the R package "meta". Forest plots were created using the metaprop function in the "meta" package, and funnel plots were constructed with the funnel function to estimate the publication bias. Egger's tests were performed to estimate the indexes of funnel asymmetry; when a funnel plot was not significantly asymmetrical, trim-andfill analyses (101) were performed. A two-sided $\mathrm{P}<0.05$ was deemed to represent the level of statistical significance.

\section{Results}

\section{Literature search and characteristics}

The search process is shown in Figure 1. A total of 2,090 articles published between 2001 and 2020 were identified through the initial database search. Of these articles, 275 reviews, 144 comments, 76 case reports, 43 editorials, and 27 meta-analyses were excluded. A further 1,352 articles were excluded based on the screening of their titles and abstracts. The remaining 173 studies were assessed on the basis of their full texts. After the exclusion of overlapping studies, studies presenting insufficient data, and studies with an inappropriate population, treatment, or size, 105 studies were finally included in the meta-analysis. Among them were 87 SBRT studies involving 12,811 patients (Table 1) and 18 RFA studies involving 1,525 patients (Table 2). There were no controlled trials or randomized studies comparing clinical outcomes between patients with early-stage NSCLC treated with SBRT and RFA. All the selected articles were single-arm observational articles or compassion studies.

The sample sizes of the SBRT studies ranged from 16 to 1,096 (median 71; mean 147) and those of the RFA studies ranged from 7 to 967 (median 33; mean 147). Patients treated with SBRT were significantly older than those treated with RFA $(74.9 \pm 3.0$ vs. $71.6 \pm 4.1$ years, respectively, $\mathrm{P} \leq 0.001)$. Significant sex differences were observed between the SBRT and RFA cohorts (percentage of males, $58.2 \%$ vs. $52.0 \%, \mathrm{P} \leq 0.001$ ). The mean follow-up time of the RFA studies was longer than that of the SBRT studies (34.2 vs. 29.3 months). Regarding the SBRT treatment regimen, the total dose ranged from 30 to $70 \mathrm{~Gy}$, and the number of fractions ranged from 1 to 10 .

\section{$L C$ rates of patients treated with SBRT and RFA}

Sixty-six SBRT and seven RFA studies reported the LC rate. For SBRT, 20 studies (2,132 patients), 31 studies 


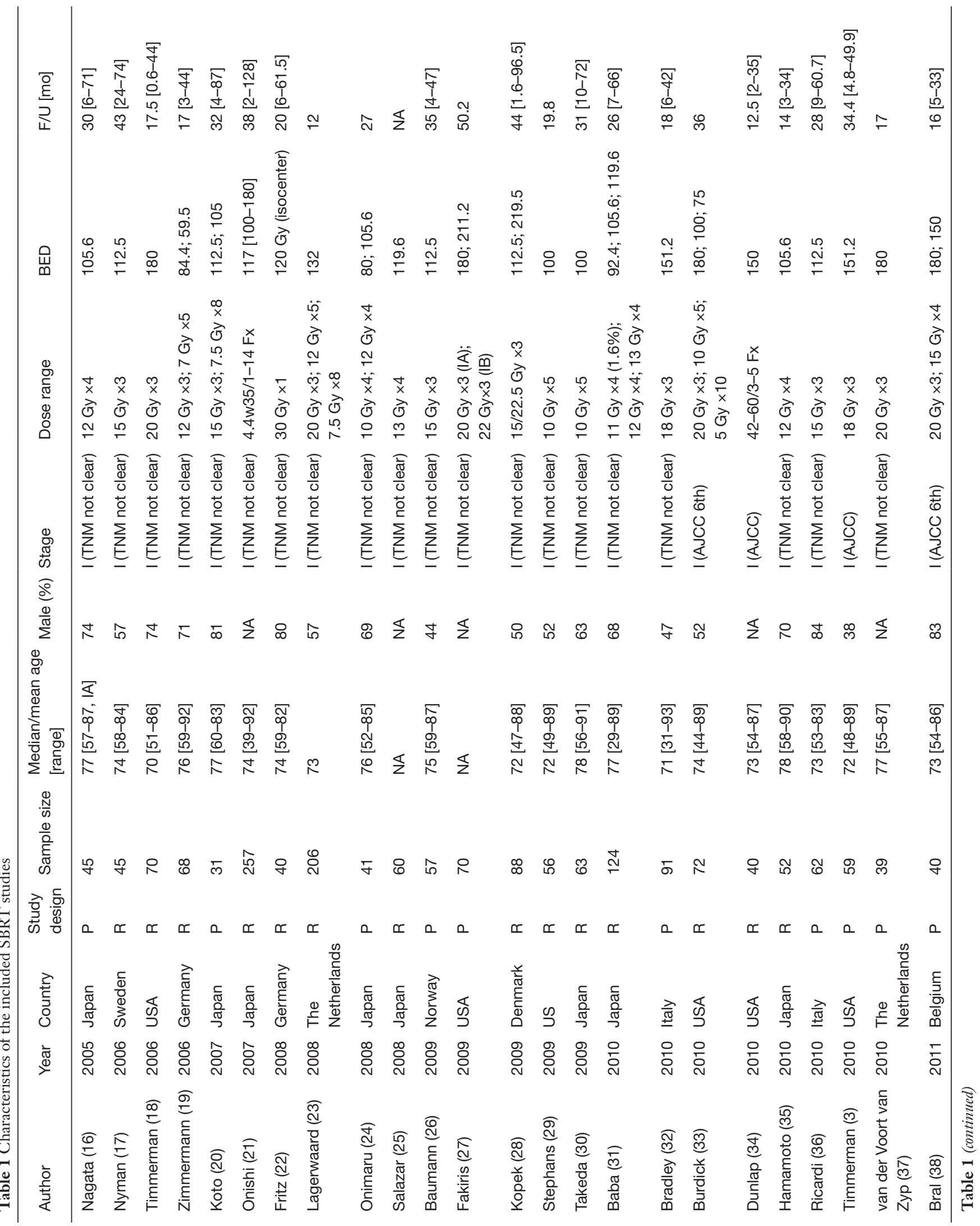




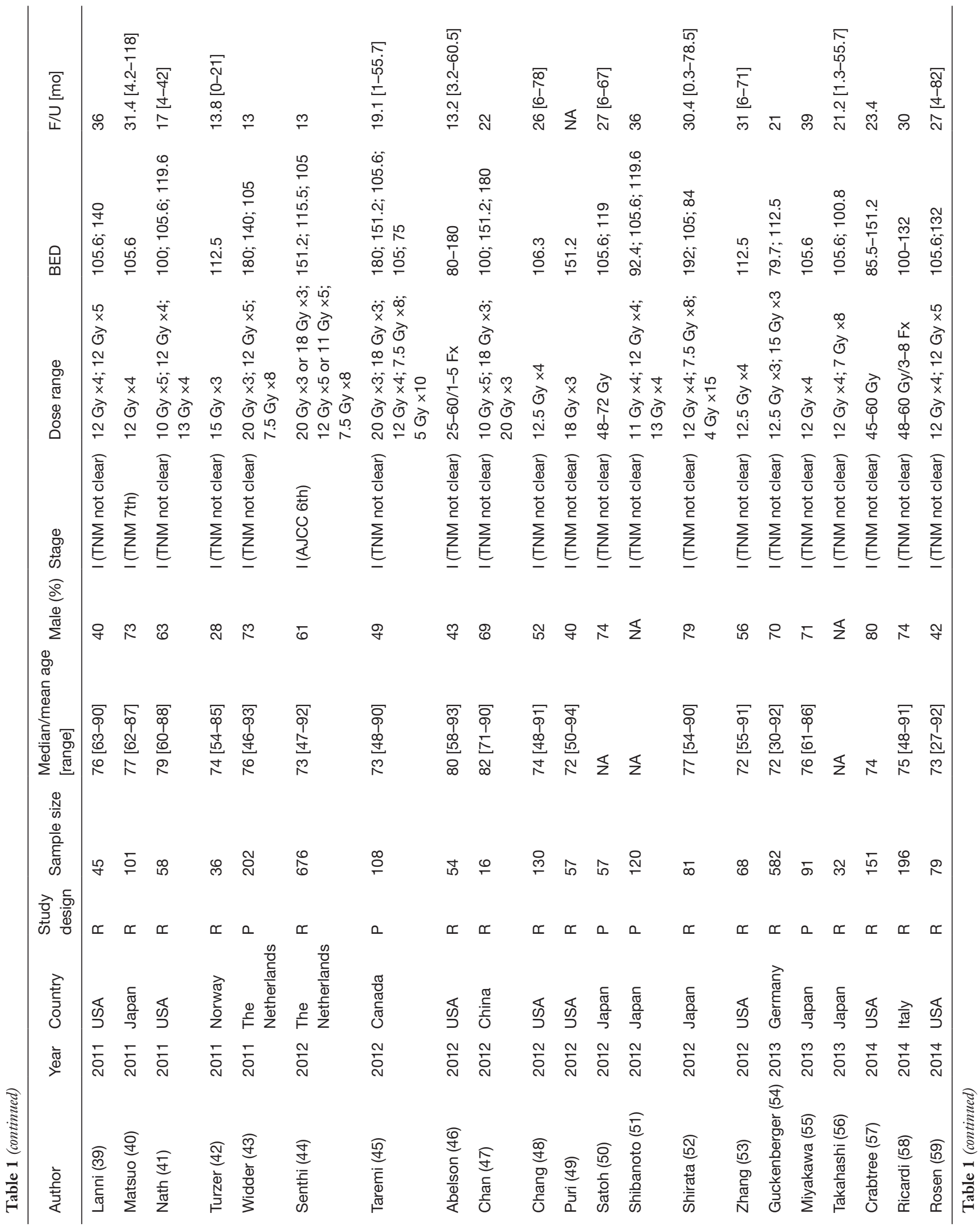




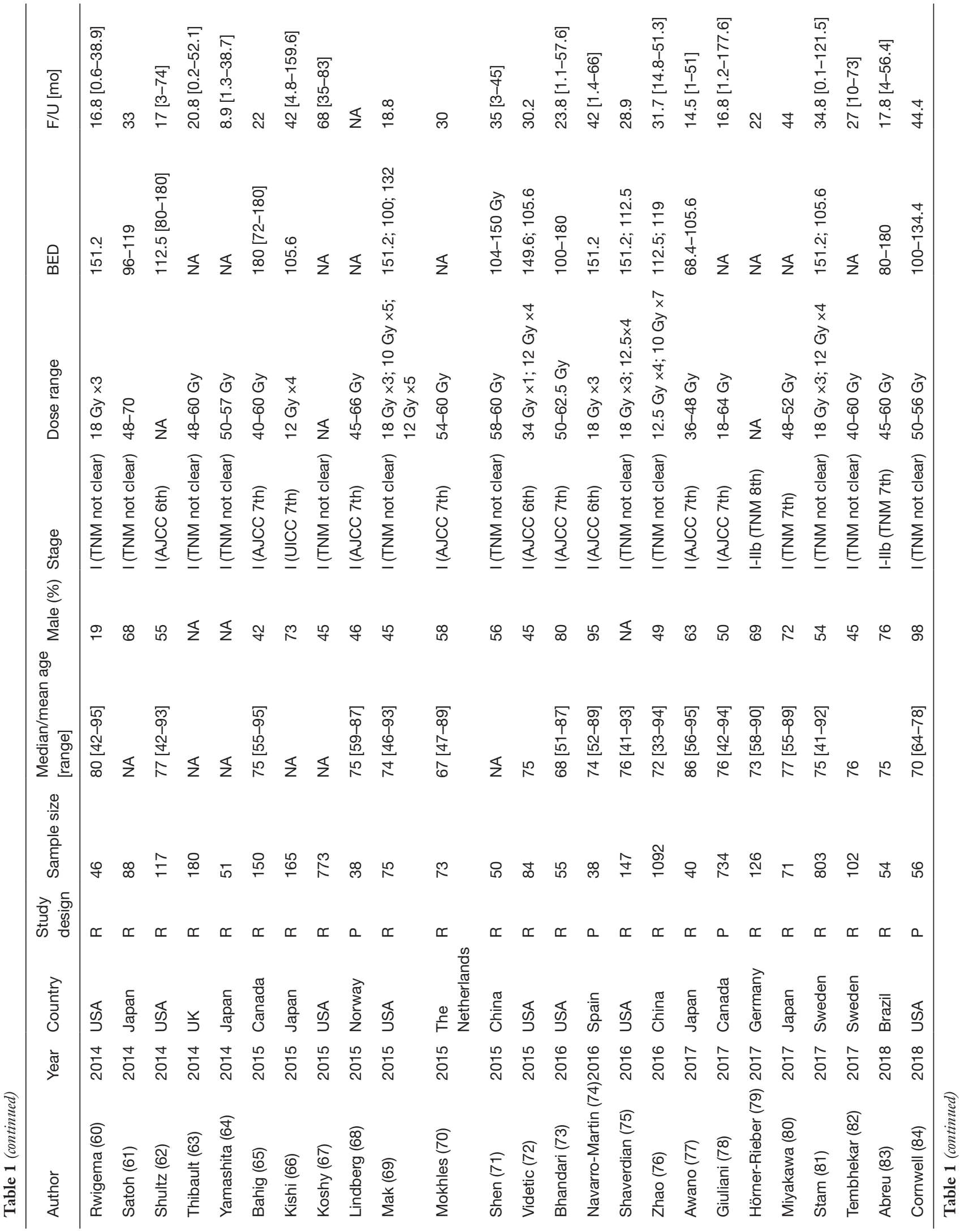




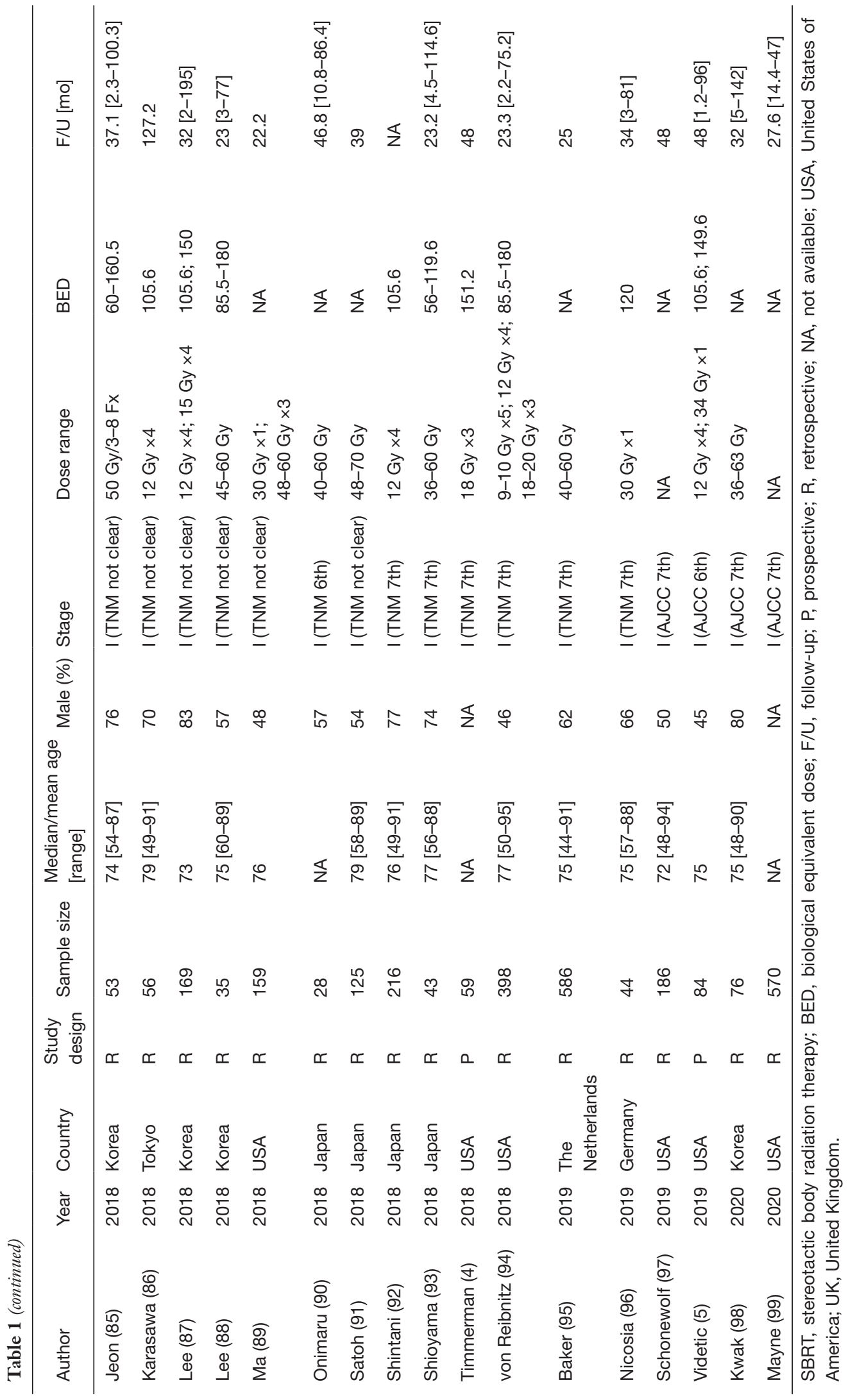




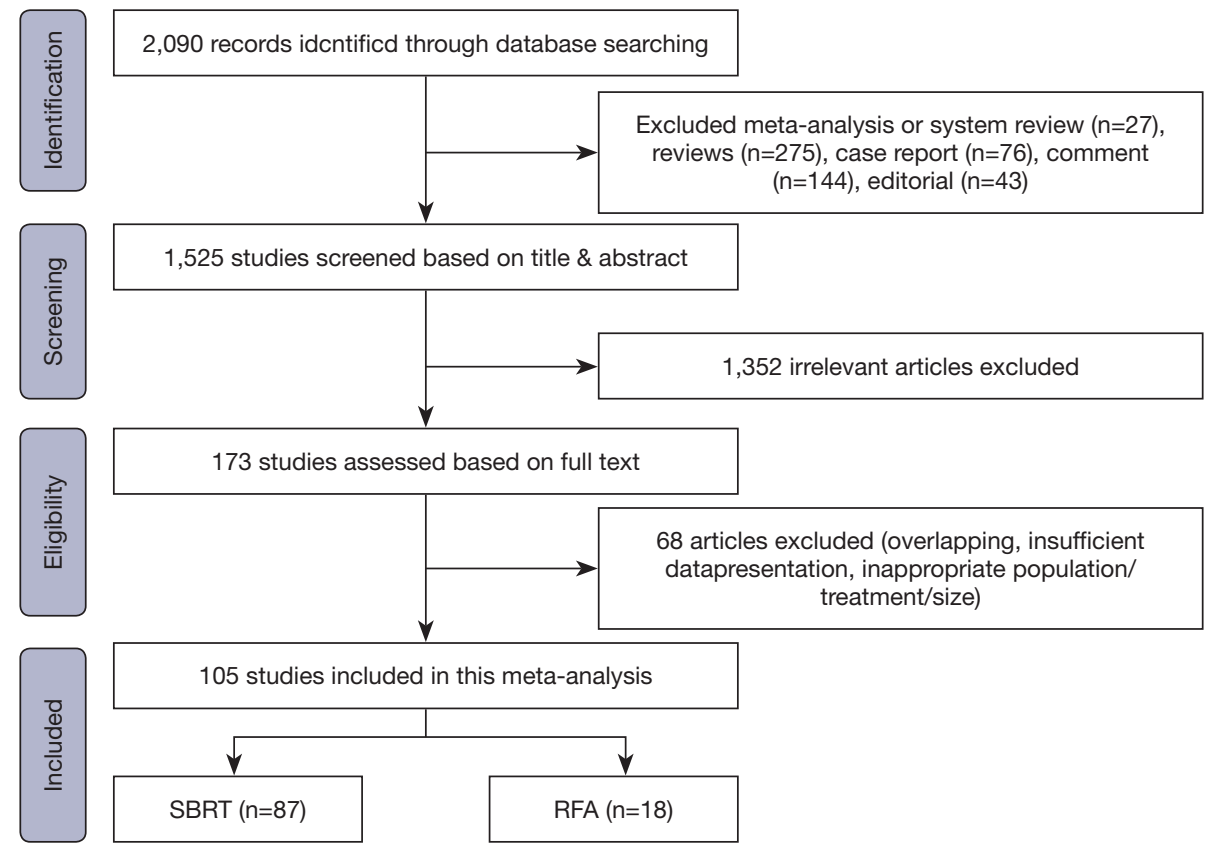

Figure 1 Flowchart of study selection.

Table 2 Characteristics of the included RFA studies

\begin{tabular}{|c|c|c|c|c|c|c|c|c|}
\hline Author & Year & Country & Study design & Sample size & Median/mean age [range] & Male (\%) & Stage & $\mathrm{F} / \mathrm{U}(\mathrm{mo})$ \\
\hline Pennathur (103) & 2007 & USA & $\mathrm{R}$ & 19 & 78 [68-88] & 42 & I (TNM not clear) & 28 [9-52] \\
\hline Simon (8) & 2007 & USA & $\mathrm{R}$ & 75 & 69 [17-94] & 57 & I (TNM not clear) & 21 [3-74] \\
\hline Lencioni (9) & 2008 & Italy & $\mathrm{P}$ & 33 & 67 [29-82] & 76 & I (TNM not clear) & $15[1-30]$ \\
\hline Zemlyak (7) & 2010 & USA & $\mathrm{R}$ & 12 & 74 [62-83] & 56 & I (TNM not clear) & 33 \\
\hline Ambrogi (105) & 2011 & Italy & $\mathrm{P}$ & 59 & $74[40-88]$ & 79 & I (TNM not clear) & 46 [12-82] \\
\hline Hess (106) & 2011 & France & $\mathrm{R}$ & 15 & 64 [42-82] & 60 & I (TNM not clear) & $17.6[2-31]$ \\
\hline Hiraki (107) & 2011 & Japan & $\mathrm{R}$ & 50 & 75 [52-88] & 58 & I (TNM not clear) & 37 [2-88] \\
\hline Kim (110) & 2012 & Korea & $\mathrm{R}$ & 8 & 72 [61-78] & 88 & I (TNM not clear) & 108 \\
\hline Lanuti (111) & 2012 & USA & $\mathrm{R}$ & 45 & 70 [51-89] & 40 & I (TNM not clear) & 32 [2-75] \\
\hline Ridge (112) & 2014 & USA & $\mathrm{R}$ & 29 & 73 [55-86] & 41 & I (TNM not clear) & 12 \\
\hline Ambrogi (113) & 2015 & Italy & $\mathrm{R}$ & 62 & 76 [60-88] & 73 & I (TNM not clear) & 42 \\
\hline Dupuy (10) & 2015 & USA & $\mathrm{R}$ & 51 & 76 [60-89] & 45 & I (TNM not clear) & 24 \\
\hline Lam (114) & 2018 & USA & $\mathrm{R}$ & 967 & 74 & 46 & I (TNM 7th) & $62.5[58.0-67.1]$ \\
\hline Palussière (11) & 2018 & France & $\mathrm{R}$ & 42 & 72 & 69 & I (TNM not clear) & NA \\
\hline
\end{tabular}

RFA, radiofrequency ablation; F/U, follow-up; P, prospective; $R$, retrospective; NA, not available. 
Table 3 Outcomes of pooled analysis for LC rates

\begin{tabular}{|c|c|c|c|c|c|c|c|}
\hline Year & \multicolumn{3}{|c|}{ SBRT } & \multicolumn{3}{|c|}{ RFA } & $P$ value \\
\hline 1 & 2,123 & $98 \%$ & $97-98 \%$ & 156 & $75 \%$ & $69-82 \%$ & 0.01 \\
\hline 2 & 4,783 & $95 \%$ & $95-96 \%$ & 85 & $31 \%$ & $22-39 \%$ & 0.01 \\
\hline 3 & 4,828 & $92 \%$ & $91-93 \%$ & 83 & $67 \%$ & $58-76 \%$ & 0.01 \\
\hline
\end{tabular}

SBRT, stereotactic body radiation therapy; RFA, radiofrequency ablation; Cl, confidence interval; LC, local control.
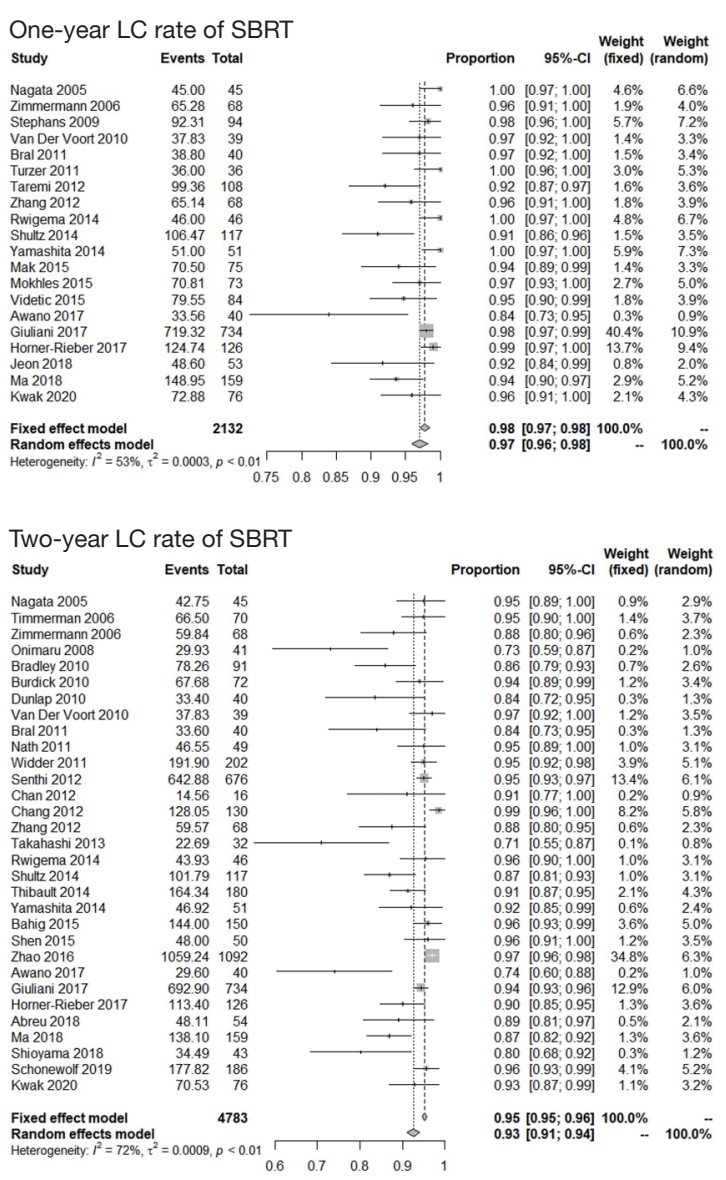

Three-year LC rate of SBRT

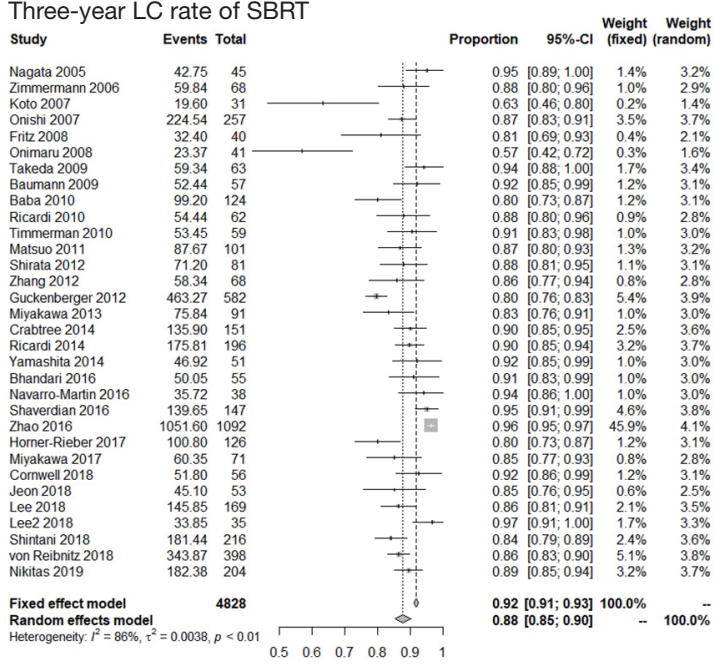

$0.92[0.91 ; 0.93] 100.0 \%$

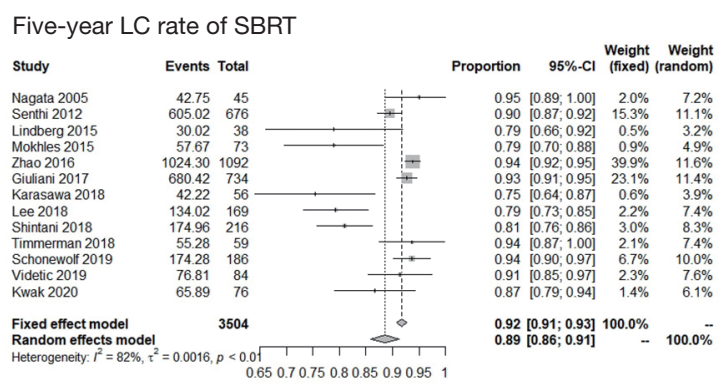

Figure 2 Meta-analysis (forest plot) of the LC rates in the SBRT studies. LC, local control; SBRT, stereotactic body radiation therapy.

(4,783 patients), 32 studies (4,828 patients), and 13 studies (3,504 patients) reported the LC rates at 1, 2, 3, and 5 years, respectively. For RFA, 6 articles (156 patients), 4 articles (85 patients), 3 articles (83 patients), and 3 articles (44 patients) reported the LC rates at $1,2,3$, and 5 years, respectively. The pooled LC rates calculated by fixed effects model are shown in Table 3, Figure 2, and Figure 3. The LC rates (with $95 \%$ CIs) for SBRT at 1, 2, 3, and 5 years were $98 \%(97-$ 98\%), 95\% (95-96\%), 92\% (91-93\%), and 92\% (91-93\%), respectively, which were significantly higher than those for RFA [75\% (69-82\%), 31\% (22-39\%), 67\% (58-76\%), and $41 \%(30-52 \%) ; \mathrm{P}<0.01]$. 

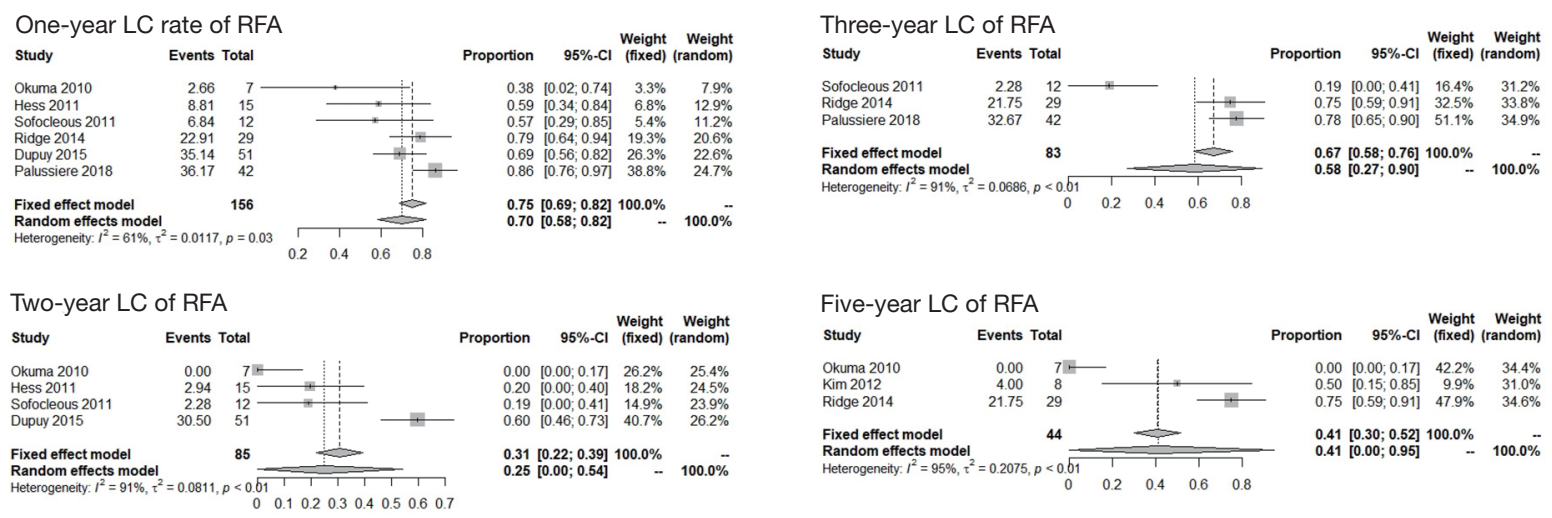

Figure 3 Meta-analysis (forest plot) of the LC rates in the RFA studies. LC, local control; RFA, radiofrequency ablation.

Table 4 Outcomes of pooled analysis for OS rates

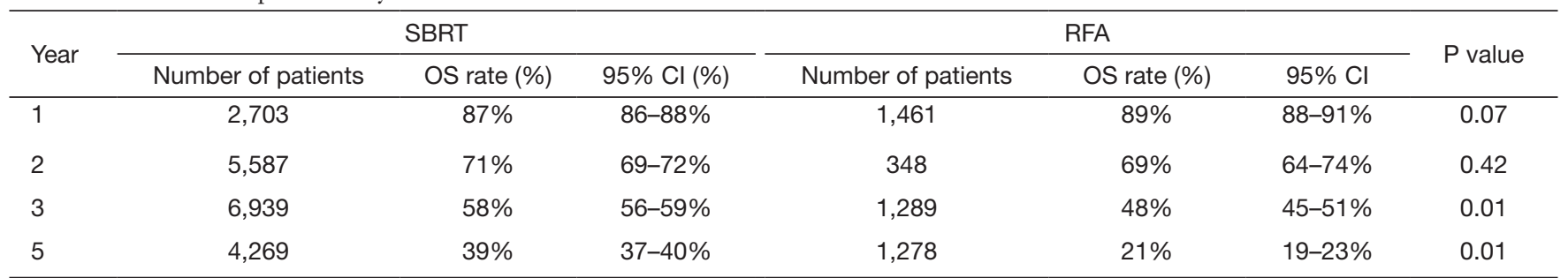

SBRT, stereotactic body radiation therapy; RFA, radiofrequency ablation; Cl, confidence interval; OS, overall survival.

\section{OS rates of patients treated with SBRT and RFA}

Eighty-two SBRT and 18 RFA studies reported OS outcomes. For SBRT, 27 articles (2,703 patients), 40 articles (5,587 patients), 45 articles (6,939 patients), and 22 articles (4,269 patients) reported the OS rate at 1, 2, 3, and 5 years, respectively. For RFA, 15 studies (1,461 patients), 11 studies (348 patients), 9 studies (1,289 patients), and 10 studies (1,278 patients) reported the OS rate at 1,2, 3 , and 5 years. The pooled OS rates calculated by fixed effects model are shown in Table 4, Figure 4, and Figure 5. Regarding short-term OS, no significant differences were observed between patients treated with SBRT and those treated with RFA at 1 year $(\mathrm{P}=0.07)$ or 2 years $(\mathrm{P}=0.42)$; for SBRT and RFA, the 1-year OS rates (with $95 \% \mathrm{CIs}$ ) were $87 \%(86-88 \%)$ and $89 \%(88-91 \%)$, respectively, and the 2 -year OS rates were $71 \%(69-72 \%)$ and $69 \%(64-74 \%)$, respectively. Regarding long-term OS, the 3 - and 5-year OS rates of patients treated with SBRT (with 95\% CIs) were 58\% (56-59\%) and 39\% (37-40\%), respectively, and were significantly $(\mathrm{P}<0.01)$ superior to those of patients treated with RFA [48\% (45-51\%) and 21\% (19-23\%)], respectively.

\section{AEs}

Data on the overall incidence of AEs following treatment with SBRT or RFA were limited (Table 5). The most common complication of RFA was pneumothorax, making up $27.2 \%$ (95\% CI, 23.2-31.1\%) of patients treated with RFA, followed by hemoptysis and pleural effusion comprised 2.2\% (95\% CI, $0.9-3.5 \%$ ) or $4.1 \%$ (95\% CI, 2.2-5.9\%). The rate of severe AEs related to SBRT (grade $\geq 3$ ) was $5.8 \%$ (95\% CI, 5.1-6.5\%), with the most common severe AE (grade $\geq 2$ ) being radiation pneumonitis, making up $9.1 \%$ (95\% CI, 8.0-10.1\%) of patients treated with SBRT. The incidence of radiation esophagitis (grade $\geq 3$ ) was low, comprising only $0.2 \%$ (95\% CI, $0.1-0.3 \%$ ) of patients treated with SBRT, and the incidence of rib fracture was $4.0 \%$ (95\% CI, 3.4-4.6\%).

\section{Sensitivity analysis and publication bias testing}

After sensitivity analysis using the elimination method, no significant change was observed in the results, which indicated their robustness. Egger's test was performed on the indexes with more than three included studies, and the results showed no obvious publication bias (Table S1). 

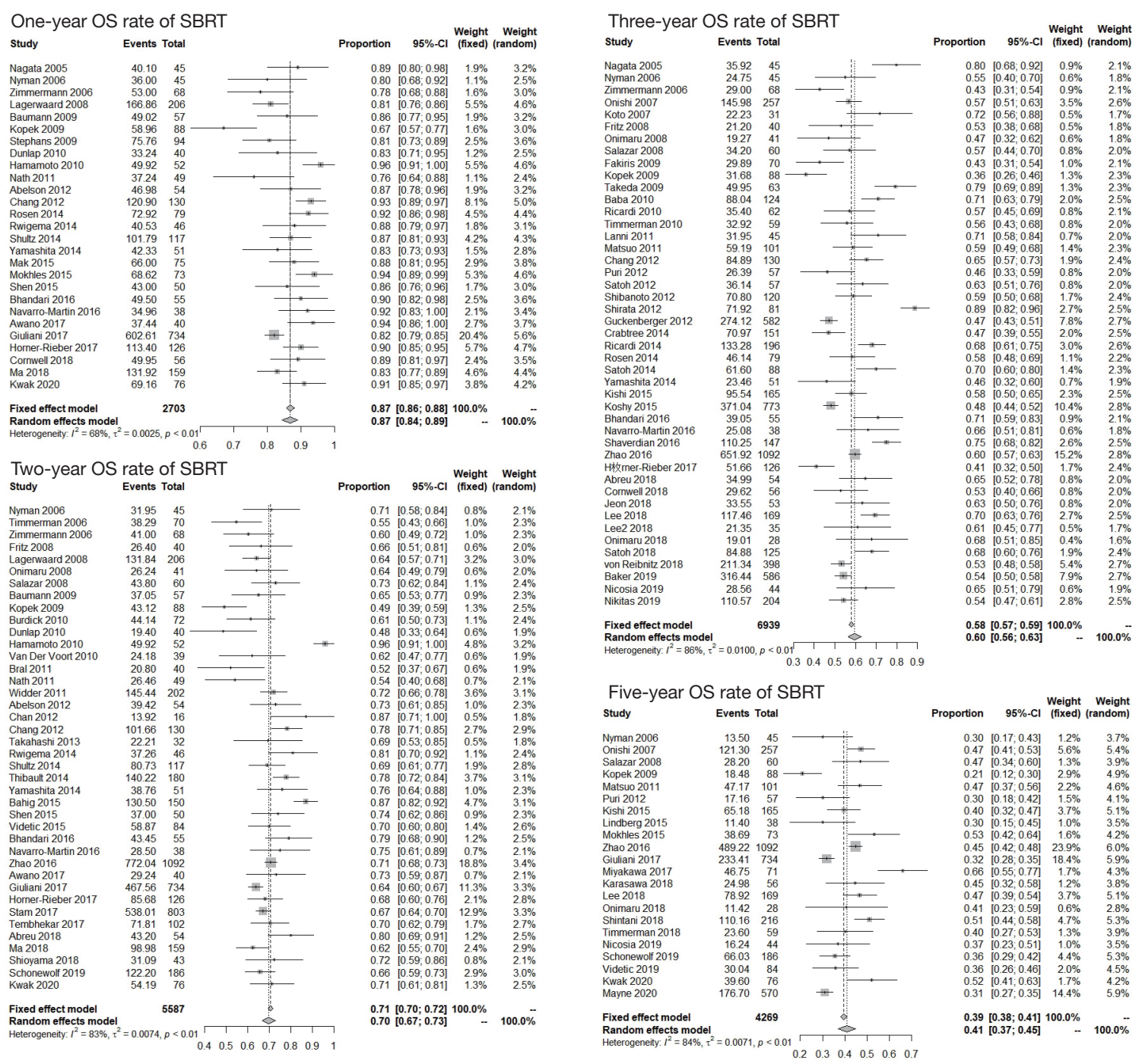

Figure 4 Meta-analysis (forest plot) of the OS rates in the SBRT studies. OS, overall survival; SBRT, stereotactic body radiation therapy.

\section{Discussion}

A total of 105 studies, including 87 SBRT studies and 18 RFA studies, were selected to compare the clinical outcomes and AEs of SBRT and RFA in patients with medically inoperable early-stage NSCLC. This comprehensive review revealed that patients who received SBRT had higher 1-, 2-, 3-, and 5-year LC rates than patients treated with RFA $(\mathrm{P}<0.01)$. After $1(\mathrm{P}=0.07)$ and $2(\mathrm{P}=0.42)$ years, the two groups of patients had comparable OS, whereas the 3 - and 5 -year OS rates were significantly higher in patients treated with SBRT $(\mathrm{P}<0.01)$. A low incidence of severe AEs was reported in both the SBRT and RFA groups.

Several previous reviews or meta-analyses have compared the outcomes of SBRT and RFA. However, no reviews or pooled analyses comparing the two have been reported in the past 5 years. In 2012, Bilal et al. (115) conducted a literature review of nine RFA studies and seven SBRT studies to compare SBRT and RFA, and found that SBRT had lower local progression rates than did RFA (3.5-14.5\% vs. $23.7-43 \%)$. They also observed that while the two treatment modalities had similar 1-year OS (68.2-95\% vs. 81-85.7\%), the SBRT cohort had a higher 5-year OS rate $(47 \%)$ than the RFA cohort (20.1-27\%), which was in line with the results of the present study. However, Bilal et al. did not utilize statistical methods to compare LC or OS between the two treatments. In 2016, Bi et al. (12) screened relevant 

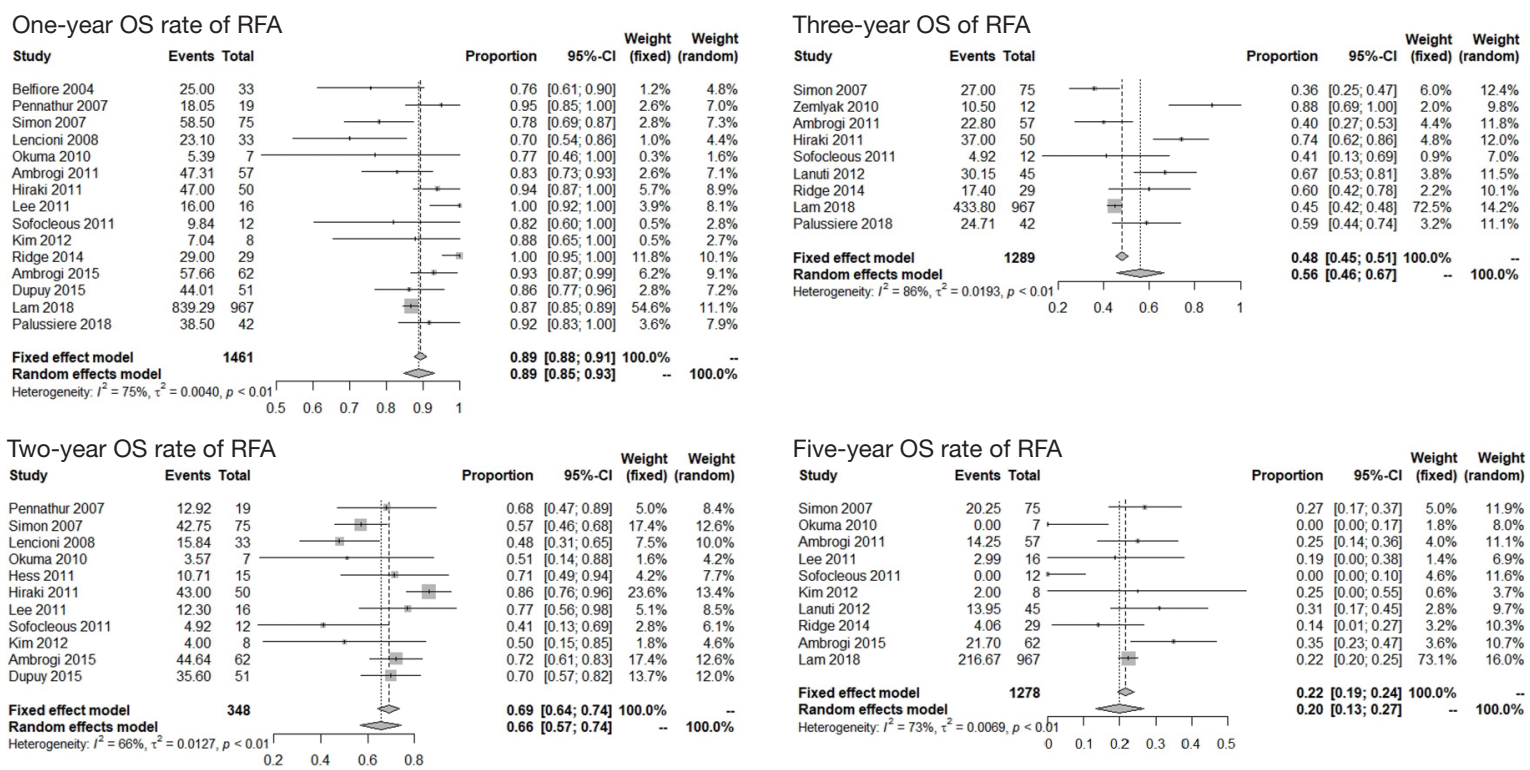

Figure 5 Meta-analysis (forest plot) of the OS rates in the RFA studies. OS, overall survival; RFA, radiofrequency ablation.

Table 5 Summary of AEs

\begin{tabular}{|c|c|c|c|c|c|}
\hline Treatment & $\mathrm{AE}$ & No. of events & No. of patients & Events percentage (\%) & $95 \% \mathrm{Cl}(\%)$ \\
\hline \multirow[t]{4}{*}{ SBRT } & RP grade $2-5$ & 270 & 2,982 & 9.1 & $(8.0-10.1)$ \\
\hline & RP grade $3-5$ & 112 & 4,244 & 2.6 & $(2.2-3.1)$ \\
\hline & Rib fracture & 163 & 4,093 & 4.0 & $(3.4-4.6)$ \\
\hline & RE grade $3-5$ & 6 & 3,244 & 0.2 & $(0.1-0.3)$ \\
\hline \multirow[t]{3}{*}{ RFA } & Pneumothorax & 132 & 486 & 27.2 & $(23.2-31.1)$ \\
\hline & Hemoptysis & 10 & 453 & 2.2 & $(0.9-3.5)$ \\
\hline & Pleural effusion & 18 & 441 & 4.1 & $(2.2-5.9)$ \\
\hline
\end{tabular}

$\mathrm{AE}$, adverse events; SBRT, stereotactic body radiation therapy; RFA, radiofrequency ablation; RP, radiation pneumonitis; RE, radiation esophagitis; $\mathrm{Cl}$, confidence interval..

studies published from 2000 to 2012, and subsequently conducted a systemic review and pooled analysis of 31 SBRT studies and 13 RFA studies. They found that the rates of LC at 1, 2, 3, and 5 years for SBRT were significantly higher than those for RFA $(97 \%, 92 \%, 88 \%$, and $86 \%$ vs. $77 \%, 48 \%, 55 \%, 42 \%$, respectively; $\mathrm{P}<0.001)$, which was consistent with the findings of the present study. However, in contrast with our study results, Bi et al. reported similar OS rates between the two treatment modalities, even at 3 and 5 years. These differences may be attributable to the fact that the OS rates reported in Bi et al.'s study were estimated pooled ratios calculated by a regression model and were not the actual pooled values. Other reasons may be that only 31 SBRT and 13 RFA studies were included, and all of them were published before 2012; since 2012, the utilization and popularity of SBRT techniques have increasingly expanded. Therefore, prospective studies containing large sample sizes to compare the clinical results of SBRT and RFA are warranted in the future to validate the findings of the present study.

Besides performing comparative analysis of the two therapeutic modalities, our study also conducted pooled 
analyses of survival outcomes in SBRT and RFA cohorts. For SBRT, 87 articles from the past 20 years, involving 11,827 patients, were included to calculate the pooled outcomes, which supports the credibility of the present pooled results. Furthermore, our pooled results echo the results of a number of prospective studies. Recently, the prospective RTOG 0236 study $(3,4)$ in the setting of inoperable early-stage NSCLC reported 3- and 5-year LC rates of $97.6 \%$ and $92.7 \%$, respectively, and 3 - and 5 -year OS rates of $55.8 \%$ and $40.0 \%$, respectively, which are in line with our findings (5-year LC rate: $92 \%$; 3 - and 5 -year OS rates: $58 \%$ and $39 \%$, respectively). Another randomized prospective study, RTOG 0915 (5), also reported similar 5 -year LC and OS rates (93.2\% and $41.1 \%$, respectively) in patients treated with 48 Gy in 4 fractions. The RTOG 0236 and RTOG 0915 trials were conducted by the North American Cooperative Group with criteria relating to SBRT, and were used to develop the infrastructure and offer high-quality treatment across multiple centers (116). Given the similar results found in this current study, it is reasonable to generalize our findings for a large population.

The present study included 18 studies on RFA from the past 20 years, involving 1,525 patients, for pooled analysis. In view of fewer articles reporting the outcomes of RFA than of SBRT in the treatment of medically inoperable early-stage NSCLC, it can be inferred that RFA is less frequently utilized and popular than SBRT. In 2008, the first prospective multicenter clinical trial, the RAPTURE study (9), reported a 2 -year OS rate of $75 \%$, which is in accordance with the 69\% 2-year OS rate observed in our study. In 2015, another prospective study reported by Dupuy et al. (10) showed similar 2-year OS and LC rates of $69.8 \%$ and $59.8 \%$, respectively. However, our study reported an LC rate of only $31 \%$ after 2 years, which may be attributable to the fact that only 4 studies and 85 patients were included in the pooled analysis for the 2-year LC rate of RFA. Recently, a prospective multicenter phase II trial (11) described LC and OS rates of $81.25 \%$ and $58.3 \%$, respectively, after 3 years, which were higher than the rates observed in our study (67\% and $48 \%$, respectively). Although this prospective study revealed RFA to produce good clinical results, the sample size was only 32 , which may not be sufficient to prove the suitability of RFA for patients with inoperable early-stage NSCLC. Therefore, despite the findings of these previous studies and our pooled analysis on RFA, further investigation is still warranted.

In terms of AEs, both treatment modalities have advantages and disadvantages which need to be weighed up by a multidisciplinary team. The major toxicities of RFA are pneumothorax, hemoptysis, and pleural effusion, which usually occur roughly 30 days after the treatment. The AEs of SBRT, which include radiation pneumonitis, rib fracture, and chest pain (117), often occur 2 to 3 months after radiation. Bi et al. (12) performed a pooled analysis of AEs for both modalities, and they found that the most common complication of RFA was pneumothorax, occurring in $31 \%$ of patients. They also discovered that severe AEs (grade $\geq 3$ ) occurred in $6.9 \%$ of patients in the SBRT cohort, with the most common severe complication (grade $\geq 3$ ) of SBRT being radiation pneumonitis, which was reported in $2.2 \%$ of patients. Our current study produced similar results regarding AEs, with the rates of severe $\mathrm{AEs}$ (grade $\geq 3$ ) and severe radiation pneumonitis (grade $\geq 2$ ) for SBRT being $5.8 \%$ and $9.1 \%$, respectively, and the rate of pneumothorax for RFA being $27.2 \%$. Summarizing AEs of SBRT or RFA can offer guidance and inform treatment during the surveillance and follow-up of patients with inoperable earlystage NSCLC.

With the rapid development of immune therapy utilized in the field of treatment for patients with lung cancer, the combination of SBRT or RFA and immunotherapy has gradually become a rational option. Both SBRT and RFA can modulate the immune function and regulate the immune microenvironment. SBRT has been proved to play an important role in the immunomodulatory process (118). Specifically, on the one hand, SBRT can activate the innate immune microenvironment by expressive upregulation of immunogenic markers, production of immunogenic cell deaths (ICDs) and release of enough tumor-associated antigens (TAAs). (119-125). On the other hand, SBRT can also elicit adaptive immune responses by acting as situ vaccine to induce the priming of cytotoxic $\mathrm{T}$ lymphocytes (CTLs) and the release of related cytokines, such as IFN- $\gamma$, which plays a vital role in the inhabitation of metastatic lesion progression (126). The expression of IFN- $\gamma$ related genes has been demonstrated to have significantly correlation with the distant non-irradiated tumor response (127), which is also famous as abscopal effect $(123,128)$. As far as the immune effect generated by RFA, similar to SBRT, RFA can alter the immunogenic nature, increase the TAAs released by tumor necrosis, and promote T cell trafficking to TME (129-132), thus activating the immune system. However, such positive immune effect seems to last about 4 weeks after ablative therapy (133).

A few clinical researches have shown that SBRT combined with immunotherapy can obtain favorable 
benefits in term of several survival outcomes, such as ORR (objective response rate), median PFS and median OS $(127,134)$. However, the combined therapy of SBRT and PD-1 (programmed death-1)/PD-L1(programmed deathligand 1) inhibitors still face some challenges concerning the optimal dose or fraction, the suitable schedule of the combined therapy, and the rational irradiated target and volume. In term of RFA, several clinical trials have also revealed more potent response for the additional immune therapy to the RFA than either PD-1/PD-L1 or RFA alone $(135,136)$. Unfortunately, incomplete ablation may induce the aggressive growth of the residual tumor lesion, the upregulation of suppressive $\mathrm{T}$ cell caused by the release of IL-10 and TGF- $\beta$, and the acceleration of tumor recurrence (137-139).

There are several limitations in this study. First, due to the nature of systematic reviews and pooled analyses, heterogeneity, caused by factors such as demographic variables, study design, radiation regimen or delivery technique disparity, and variation in clinical outcome definitions, was present. However, this systematic review and pooled analysis including more than 14,000 patients can, to a certain degree, offer benefit in the guidance of treatment options (140). Second, our current pooled analysis included studies published between 2000 and 2020, and the techniques of both SBRT and RFA may have evolved during those two decades, which could have resulted in inconsistencies between the studies. Third, SBRT may offer a suitable option for salvage treatment (141), but the current study did not include articles focusing on this area. However, Steber et al. (142) found that SBRT alone offered similar or even superior LC to RFA and SBRT combined.

\section{Conclusions}

This systematic review and pooled analysis have revealed that compared to RFA, SBRT has superior LC rates and long-term OS rates, but similar short-term OS rates. Prospective randomized trials or studies with large sample sizes are needed to validate these findings.

\section{Acknowledgments}

The primary results of the abstract in this study were presented as a meeting poster (No. 545) in the 2021 World Conference on Lung Cancer.

Funding: This research was supported by the Start-up Fund for Talent Introduction of Shanghai Pulmonary
Hospital (YX) (grant No. 201801) and the Science Research Foundation of China Ministry of Health-Zhejiang Medicine \& Health Key Research Fund (grant No. 201339868).

\section{Footnote}

Reporting Checklist: The authors have completed the PRISMA reporting checklist. Available at https://atm. amegroups.com/article/view/10.21037/atm-21-6256/rc

Conflicts of Interest: All authors have completed the ICMJE uniform disclosure form (available at https://atm. amegroups.com/article/view/10.21037/atm-21-6256/coif). The authors have no conflicts of interest to declare.

Ethical Statement: The authors are accountable for all aspects of the work in ensuring that questions related to the accuracy or integrity of any part of the work are appropriately investigated and resolved.

Open Access Statement: This is an Open Access article distributed in accordance with the Creative Commons Attribution-NonCommercial-NoDerivs 4.0 International License (CC BY-NC-ND 4.0), which permits the noncommercial replication and distribution of the article with the strict proviso that no changes or edits are made and the original work is properly cited (including links to both the formal publication through the relevant DOI and the license). See: https://creativecommons.org/licenses/by-nc-nd/4.0/.

\section{References}

1. Timmerman RD, Paulus R, Pass HI, et al. Stereotactic Body Radiation Therapy for Operable Early-Stage Lung Cancer: Findings From the NRG Oncology RTOG 0618 Trial. JAMA Oncol 2018;4:1263-6.

2. NCCN. Network, NCC Non-small Cell Lung Cancer (Version 6 2020). Available online: https://wwwnccnorg/ professionals/physician_gls/pdf/nsclpdf

3. Timmerman R, Paulus R, Galvin J, et al. Stereotactic body radiation therapy for inoperable early stage lung cancer. JAMA 2010;303:1070-6.

4. Timmerman RD, Hu C, Michalski JM, et al. Longterm Results of Stereotactic Body Radiation Therapy in Medically Inoperable Stage I Non-Small Cell Lung Cancer. JAMA Oncol 2018;4:1287-8.

5. Videtic GM, Paulus R, Singh AK, et al. Long-term Follow-up on NRG Oncology RTOG 0915 (NCCTG 
N0927): A Randomized Phase 2 Study Comparing 2 Stereotactic Body Radiation Therapy Schedules for Medically Inoperable Patients With Stage I Peripheral Non-Small Cell Lung Cancer. Int J Radiat Oncol Biol Phys 2019;103:1077-84.

6. Ahmed M, Brace CL, Lee FT Jr, et al. Principles of and advances in percutaneous ablation. Radiology 2011;258:351-69.

7. Zemlyak A, Moore WH, Bilfinger TV. Comparison of survival after sublobar resections and ablative therapies for stage I non-small cell lung cancer. J Am Coll Surg 2010;211:68-72.

8. Simon CJ, Dupuy DE, DiPetrillo TA, et al. Pulmonary radiofrequency ablation: long-term safety and efficacy in 153 patients. Radiology 2007;243:268-75.

9. Lencioni R, Crocetti L, Cioni R, et al. Response to radiofrequency ablation of pulmonary tumours: a prospective, intention-to-treat, multicentre clinical trial (the RAPTURE study). Lancet Oncol 2008;9:621-8.

10. Dupuy DE, Fernando HC, Hillman S, et al. Radiofrequency ablation of stage IA non-small cell lung cancer in medically inoperable patients: Results from the American College of Surgeons Oncology Group Z4033 (Alliance) trial. Cancer 2015;121:3491-8.

11. Palussière J, Chomy F, Savina M, et al. Radiofrequency ablation of stage IA non-small cell lung cancer in patients ineligible for surgery: results of a prospective multicenter phase II trial. J Cardiothorac Surg 2018;13:91.

12. Bi N, Shedden K, Zheng X, et al. Comparison of the Effectiveness of Radiofrequency Ablation With Stereotactic Body Radiation Therapy in Inoperable Stage I Non-Small Cell Lung Cancer: A Systemic Review and Pooled Analysis. Int J Radiat Oncol Biol Phys 2016;95:1378-90.

13. Ager BJ, Wells SM, Gruhl JD, et al. Stereotactic body radiotherapy versus percutaneous local tumor ablation for early-stage non-small cell lung cancer. Lung Cancer 2019;138:6-12.

14. Iyengar P, Westover K, Timmerman RD. Stereotactic ablative radiotherapy (SABR) for non-small cell lung cancer. Semin Respir Crit Care Med 2013;34:845-54.

15. Liberati A, Altman DG, Tetzlaff J, et al. The PRISMA statement for reporting systematic reviews and metaanalyses of studies that evaluate health care interventions: explanation and elaboration. J Clin Epidemiol 2009;62:e1-34.

16. Nagata Y, Takayama K, Matsuo Y, et al. Clinical outcomes of a phase I/II study of 48 Gy of stereotactic body radiotherapy in 4 fractions for primary lung cancer using a stereotactic body frame. Int J Radiat Oncol Biol Phys 2005;63:1427-31.

17. Nyman J, Johansson KA, Hultén U. Stereotactic hypofractionated radiotherapy for stage I non-small cell lung cancer--mature results for medically inoperable patients. Lung Cancer 2006;51:97-103.

18. Timmerman R, McGarry R, Yiannoutsos C, et al. Excessive toxicity when treating central tumors in a phase II study of stereotactic body radiation therapy for medically inoperable early-stage lung cancer. J Clin Oncol 2006;24:4833-9.

19. Zimmermann FB, Geinitz H, Schill S, et al. Stereotactic hypofractionated radiotherapy in stage I (T1-2 N0 M0) non-small-cell lung cancer (NSCLC). Acta Oncol 2006;45:796-801.

20. Koto M, Takai Y, Ogawa Y, et al. A phase II study on stereotactic body radiotherapy for stage I non-small cell lung cancer. Radiother Oncol 2007;85:429-34.

21. Onishi H, Shirato H, Nagata Y, et al. Hypofractionated stereotactic radiotherapy (HypoFXSRT) for stage I nonsmall cell lung cancer: updated results of 257 patients in a Japanese multi-institutional study. J Thorac Oncol 2007;2:S94-100.

22. Fritz P, Kraus HJ, Blaschke T, et al. Stereotactic, high single-dose irradiation of stage I non-small cell lung cancer (NSCLC) using four-dimensional CT scans for treatment planning. Lung Cancer 2008;60:193-9.

23. Lagerwaard FJ, Haasbeek CJ, Smit EF, et al. Outcomes of risk-adapted fractionated stereotactic radiotherapy for stage I non-small-cell lung cancer. Int J Radiat Oncol Biol Phys 2008;70:685-92.

24. Onimaru R, Fujino M, Yamazaki K, et al. Steep doseresponse relationship for stage I non-small-cell lung cancer using hypofractionated high-dose irradiation by real-time tumor-tracking radiotherapy. Int J Radiat Oncol Biol Phys 2008;70:374-81.

25. Salazar OM, Sandhu TS, Lattin PB, et al. Once-weekly, high-dose stereotactic body radiotherapy for lung cancer: 6-year analysis of 60 early-stage, 42 locally advanced, and 7 metastatic lung cancers. Int J Radiat Oncol Biol Phys 2008;72:707-15.

26. Baumann P, Nyman J, Hoyer M, et al. Outcome in a prospective phase II trial of medically inoperable stage I non-small-cell lung cancer patients treated with stereotactic body radiotherapy. J Clin Oncol 
2009;27:3290-6.

27. Fakiris AJ, McGarry RC, Yiannoutsos CT, et al. Stereotactic body radiation therapy for early-stage non-small-cell lung carcinoma: four-year results of a prospective phase II study. Int J Radiat Oncol Biol Phys 2009;75:677-82.

28. Kopek N, Paludan M, Petersen J, et al. Co-morbidity index predicts for mortality after stereotactic body radiotherapy for medically inoperable early-stage nonsmall cell lung cancer. Radiother Oncol 2009;93:402-7.

29. Stephans KL, Djemil T, Reddy CA, et al. A comparison of two stereotactic body radiation fractionation schedules for medically inoperable stage I non-small cell lung cancer: the Cleveland Clinic experience. J Thorac Oncol 2009;4:976-82.

30. Takeda A, Sanuki N, Kunieda E, et al. Stereotactic body radiotherapy for primary lung cancer at a dose of $50 \mathrm{~Gy}$ total in five fractions to the periphery of the planning target volume calculated using a superposition algorithm. Int J Radiat Oncol Biol Phys 2009;73:442-8.

31. Baba F, Shibamoto Y, Ogino H, et al. Clinical outcomes of stereotactic body radiotherapy for stage I non-small cell lung cancer using different doses depending on tumor size. Radiat Oncol 2010;5:81.

32. Bradley JD, El Naqa I, Drzymala RE, et al. Stereotactic body radiation therapy for early-stage non-small-cell lung cancer: the pattern of failure is distant. Int J Radiat Oncol Biol Phys 2010;77:1146-50.

33. Burdick MJ, Stephans KL, Reddy CA, et al. Maximum standardized uptake value from staging FDG-PET/ CT does not predict treatment outcome for early-stage non-small-cell lung cancer treated with stereotactic body radiotherapy. Int J Radiat Oncol Biol Phys 2010;78:1033-9.

34. Dunlap NE, Larner JM, Read PW, et al. Size matters: a comparison of T1 and T2 peripheral non-small-cell lung cancers treated with stereotactic body radiation therapy (SBRT). J Thorac Cardiovasc Surg 2010;140:583-9.

35. Hamamoto Y, Kataoka M, Yamashita M, et al. Local control of metastatic lung tumors treated with SBRT of 48 Gy in four fractions: in comparison with primary lung cancer. Jpn J Clin Oncol 2010;40:125-9.

36. Ricardi U, Filippi AR, Guarneri A, et al. Stereotactic body radiation therapy for early stage non-small cell lung cancer: results of a prospective trial. Lung Cancer 2010;68:72-7.

37. van der Voort van Zyp NC, Prévost JB, van der Holt B, et al. Quality of life after stereotactic radiotherapy for stage
I non-small-cell lung cancer. Int J Radiat Oncol Biol Phys 2010;77:31-7.

38. Bral S, Gevaert T, Linthout N, et al. Prospective, riskadapted strategy of stereotactic body radiotherapy for early-stage non-small-cell lung cancer: results of a Phase II trial. Int J Radiat Oncol Biol Phys 2011;80:1343-9.

39. Lanni TB Jr, Grills IS, Kestin LL, et al. Stereotactic radiotherapy reduces treatment cost while improving overall survival and local control over standard fractionated radiation therapy for medically inoperable non-small-cell lung cancer. Am J Clin Oncol 2011;34:494-8.

40. Matsuo Y, Shibuya K, Nagata Y, et al. Prognostic factors in stereotactic body radiotherapy for non-small-cell lung cancer. Int J Radiat Oncol Biol Phys 2011;79:1104-11.

41. Nath SK, Sandhu AP, Kim D, et al. Locoregional and distant failure following image-guided stereotactic body radiation for early-stage primary lung cancer. Radiother Oncol 2011;99:12-7.

42. Turzer M, Brustugun OT, Waldeland E, et al. Stereotactic body radiation therapy is effective and safe in patients with early-stage non-small cell lung cancer with low performance status and severe comorbidity. Case Rep Oncol 2011;4:25-34.

43. Widder J, Postmus D, Ubbels JF, et al. Survival and quality of life after stereotactic or 3D-conformal radiotherapy for inoperable early-stage lung cancer. Int J Radiat Oncol Biol Phys 2011;81:e291-7.

44. Senthi S, Lagerwaard FJ, Haasbeek CJ, et al. Patterns of disease recurrence after stereotactic ablative radiotherapy for early stage non-small-cell lung cancer: a retrospective analysis. Lancet Oncol 2012;13:802-9.

45. Taremi M, Hope A, Dahele M, et al. Stereotactic body radiotherapy for medically inoperable lung cancer: prospective, single-center study of 108 consecutive patients. Int J Radiat Oncol Biol Phys 2012;82:967-73.

46. Abelson JA, Murphy JD, Trakul N, et al. Metabolic imaging metrics correlate with survival in early stage lung cancer treated with stereotactic ablative radiotherapy. Lung Cancer 2012;78:219-24.

47. Chan OS, Yeung RM, Hung AW, et al. Stereotactic ablative radiotherapy for medically inoperable early stage lung cancer: early outcomes. Hong Kong Med J 2012;18:412-8.

48. Chang JY, Liu H, Balter P, et al. Clinical outcome and predictors of survival and pneumonitis after stereotactic ablative radiotherapy for stage I non-small cell lung cancer. Radiat Oncol 2012;7:152.

49. Puri V, Crabtree TD, Kymes S, et al. A comparison of 
surgical intervention and stereotactic body radiation therapy for stage I lung cancer in high-risk patients: a decision analysis. J Thorac Cardiovasc Surg 2012;143:428-36.

50. Satoh Y, Nambu A, Onishi H, et al. Value of dual time point F-18 FDG-PET/CT imaging for the evaluation of prognosis and risk factors for recurrence in patients with stage I non-small cell lung cancer treated with stereotactic body radiation therapy. Eur J Radiol 2012;81:3530-4.

51. Shibamoto Y, Hashizume C, Baba F, et al. Stereotactic body radiotherapy using a radiobiology-based regimen for stage I nonsmall cell lung cancer: a multicenter study. Cancer 2012;118:2078-84.

52. Shirata $Y$, Jingu K, Koto M, et al. Prognostic factors for local control of stage I non-small cell lung cancer in stereotactic radiotherapy: a retrospective analysis. Radiat Oncol 2012;7:182.

53. Zhang X, Liu H, Balter P, et al. Positron emission tomography for assessing local failure after stereotactic body radiotherapy for non-small-cell lung cancer. Int J Radiat Oncol Biol Phys 2012;83:1558-65.

54. Guckenberger M, Allgäuer M, Appold S, et al. Safety and efficacy of stereotactic body radiotherapy for stage 1 non-small-cell lung cancer in routine clinical practice: a patterns-of-care and outcome analysis. J Thorac Oncol 2013;8:1050-8.

55. Miyakawa A, Shibamoto Y, Kosaki K, et al. Early response and local control of stage I non-small-cell lung cancer after stereotactic radiotherapy: difference by histology. Cancer Sci 2013;104:130-4.

56. Takahashi W, Yamashita H, Omori M, et al. The feasibility and efficacy of stereotactic body radiotherapy for centrallylocated lung tumors. Anticancer Res 2013;33:4959-64.

57. Crabtree TD, Puri V, Robinson C, et al. Analysis of first recurrence and survival in patients with stage I nonsmall cell lung cancer treated with surgical resection or stereotactic radiation therapy. J Thorac Cardiovasc Surg 2014;147:1183-1191; discussion 1191-2.

58. Ricardi U, Frezza G, Filippi AR, et al. Stereotactic Ablative Radiotherapy for stage I histologically proven non-small cell lung cancer: an Italian multicenter observational study. Lung Cancer 2014;84:248-53.

59. Rosen LR, Fischer-Valuck BW, Katz SR, et al. Helical image-guided stereotactic body radiotherapy (SBRT) for the treatment of early-stage lung cancer: a singleinstitution experience at the Willis-Knighton Cancer Center. Tumori 2014;100:42-8.

60. Rwigema JC, Chen AM, Wang PC, et al. Incidental mediastinal dose does not explain low mediastinal node recurrence rates in patients with early-stage NSCLC treated with stereotactic body radiotherapy. Clin Lung Cancer 2014;15:287-93.

61. Satoh Y, Onishi H, Nambu A, et al. Volume-based parameters measured by using FDG PET/CT in patients with stage I NSCLC treated with stereotactic body radiation therapy: prognostic value. Radiology 2014;270:275-81.

62. Shultz DB, Trakul N, Abelson JA, et al. Imaging features associated with disease progression after stereotactic ablative radiotherapy for stage I non-small-cell lung cancer. Clin Lung Cancer 2014;15:294-301.e3.

63. Thibault I, Poon I, Yeung L, et al. Predictive factors for local control in primary and metastatic lung tumours after four to five fraction stereotactic ablative body radiotherapy: a single institution's comprehensive experience. Clin Oncol (R Coll Radiol) 2014;26:713-9.

64. Yamashita H, Haga A, Takahashi W, et al. Volumetric modulated arc therapy for lung stereotactic radiation therapy can achieve high local control rates. Radiat Oncol 2014;9:243.

65. Bahig H, Filion E, Vu T, et al. Excellent Cancer Outcomes Following Patient-adapted Robotic Lung SBRT But a Case for Caution in Idiopathic Pulmonary Fibrosis. Technol Cancer Res Treat 2015;14:667-76.

66. Kishi T, Matsuo Y, Ueki N, et al. Pretreatment Modified Glasgow Prognostic Score Predicts Clinical Outcomes After Stereotactic Body Radiation Therapy for Early-Stage Non-Small Cell Lung Cancer. Int J Radiat Oncol Biol Phys 2015;92:619-26.

67. Koshy M, Malik R, Mahmood U, et al. Stereotactic body radiotherapy and treatment at a high volume facility is associated with improved survival in patients with inoperable stage I non-small cell lung cancer. Radiother Oncol 2015;114:148-54.

68. Lindberg K, Nyman J, Riesenfeld Källskog V, et al. Longterm results of a prospective phase II trial of medically inoperable stage I NSCLC treated with SBRT - the Nordic experience. Acta Oncol 2015;54:1096-104.

69. Mak RH, Hermann G, Lewis JH, et al. Outcomes by tumor histology and KRAS mutation status after lung stereotactic body radiation therapy for early-stage nonsmall-cell lung cancer. Clin Lung Cancer 2015;16:24-32.

70. Mokhles S, Verstegen N, Maat AP, et al. Comparison of clinical outcome of stage I non-small cell lung cancer treated surgically or with stereotactic radiotherapy: results from propensity score analysis. Lung Cancer 
2015;87:283-9.

71. Shen ZT, Wu XH, Li B, et al. Clinical outcomes of CyberKnife stereotactic body radiotherapy for peripheral stage I non-small cell lung cancer. Med Oncol 2015;32:55.

72. Videtic GM, Hu C, Singh AK, et al. A Randomized Phase 2 Study Comparing 2 Stereotactic Body Radiation Therapy Schedules for Medically Inoperable Patients With Stage I Peripheral Non-Small Cell Lung Cancer: NRG Oncology RTOG 0915 (NCCTG N0927). Int J Radiat Oncol Biol Phys 2015;93:757-64.

73. Bhandari RP, Stanford JD, Packianathan S, et al. Stereotactic Body Radiation Therapy for Stage I NonSmall Cell Lung Cancer: A Retrospective, Single-Center Study of 55 Patients. Oncology 2016;91:194-204.

74. Navarro-Martin A, Aso S, Cacicedo J, et al. Phase II Trial of SBRT for Stage I NSCLC: Survival, Local Control, and Lung Function at 36 Months. J Thorac Oncol 2016;11:1101-11.

75. Shaverdian N, Veruttipong D, Wang J, et al. Pretreatment Anemia Portends Poor Survival and Nonlocal Disease Progression in Patients with Stage I Non-Small Cell Lung Cancer Treated with Stereotactic Body Radiation Therapy. J Thorac Oncol 2016;11:1319-25.

76. Zhao L, Zhou S, Balter P, et al. Planning Target Volume D95 and Mean Dose Should Be Considered for Optimal Local Control for Stereotactic Ablative Radiation Therapy. Int J Radiat Oncol Biol Phys 2016;95:1226-35.

77. Awano N, Ikushima S, Izumo T, et al. Efficacy and safety of stereotactic body radiotherapy using CyberKnife in Stage I primary lung tumor. Jpn J Clin Oncol 2017;47:969-75.

78. Giuliani ME, Hope A, Mangona V, et al. Predictors and Patterns of Regional Recurrence Following Lung SBRT: A Report From the Elekta Lung Research Group. Clin Lung Cancer 2017;18:162-8.

79. Hörner-Rieber J, Bernhardt D, Dern J, et al. Histology of non-small cell lung cancer predicts the response to stereotactic body radiotherapy. Radiother Oncol 2017;125:317-24.

80. Miyakawa A, Shibamoto Y, Baba F, et al. Stereotactic body radiotherapy for stage I non-small-cell lung cancer using higher doses for larger tumors: results of the second study. Radiat Oncol 2017;12:152.

81. Stam B, Peulen H, Guckenberger M, et al. Dose to heart substructures is associated with non-cancer death after SBRT in stage I-II NSCLC patients. Radiother Oncol 2017;123:370-5.

82. Tembhekar AR, Wright CL, Daly ME. Cardiac Dose and
Survival After Stereotactic Body Radiotherapy for Earlystage Non-Small-cell Lung Cancer. Clin Lung Cancer 2017;18:293-8.

83. Abreu CECV, Moraes FY, Miranda FA, et al. Stereotactic Body Radiation Therapy for Biopsy-Proven Primary NonSmall-Cell Lung Cancer: Experience of Patients With Inoperable Cancer at a Single Brazilian Institution. J Glob Oncol 2018;4:1-8.

84. Cornwell LD, Echeverria AE, Samuelian J, et al. Videoassisted thoracoscopic lobectomy is associated with greater recurrence-free survival than stereotactic body radiotherapy for clinical stage I lung cancer. J Thorac Cardiovasc Surg 2018;155:395-402.

85. Jeon W, Ahn SJ, Kim YC, et al. Correlation of biologically effective dose and the tumor control in Stage $\mathrm{I}(<5 \mathrm{~cm})$ non-small cell lung cancer with stereotactic ablative radiotherapy: a single institutional cohort study. Jpn J Clin Oncol 2018;48:144-52.

86. Karasawa K, Hayakawa S, Machitori Y, et al. Accelerated Hypofractionated Radiotherapy Versus Stereotactic Body Radiotherapy for the Treatment of Stage I Nonsmall Cell Lung Cancer-A Single Institution Experience With Long-Term Follow-Up. Technol Cancer Res Treat 2018;17:1533033818806318.

87. Lee S, Song SY, Kim SS, et al. Feasible Optimization of Stereotactic Ablative Radiotherapy Dose by Tumor Size for Stage I Non-small-cell Lung Cancer. Clin Lung Cancer 2018;19:e253-61.

88. Lee J, Lee M, Koom WS, et al. Metabolic positron emission tomography parameters predict failure patterns in early non-small-cell lung cancer treated with stereotactic body radiation therapy: a single institution experience. Jpn J Clin Oncol 2018;48:920-6.

89. Ma SJ, Serra LM, Syed YA, et al. Comparison of Singleand Three-fraction Schedules of Stereotactic Body Radiation Therapy for Peripheral Early-stage Non-Smallcell Lung Cancer. Clin Lung Cancer 2018;19:e235-40.

90. Onimaru R, Onishi H, Ogawa G, et al. Final report of survival and late toxicities in the Phase I study of stereotactic body radiation therapy for peripheral T2N0M0 non-small cell lung cancer (JCOG0702). Jpn J Clin Oncol 2018;48:1076-82.

91. Satoh Y, Motosugi U, Saito A, et al. Pretreatment 18F-fluorodeoxyglucose Uptake in the Lung Parenchyma Predicts Poor Survival After Stereotactic Body Radiation Therapy in Patients With Stage I NonSmall Cell Lung Cancer. Technol Cancer Res Treat 2018;17:1533033818794934. 
92. Shintani T, Matsuo Y, lizuka Y, et al. A Retrospective Long-term Follow-up Study of Stereotactic Body Radiation Therapy for Non-Small Cell Lung Cancer From a Single Institution: Incidence of Late Local Recurrence. Int J Radiat Oncol Biol Phys 2018;100:1228-36.

93. Shioyama Y, Onishi H, Takayama K, et al. Clinical Outcomes of Stereotactic Body Radiotherapy for Patients With Stage I Small-Cell Lung Cancer: Analysis of a Subset of the Japanese Radiological Society Multi-Institutional SBRT Study Group Database. Technol Cancer Res Treat 2018;17:1533033818783904.

94. von Reibnitz D, Shaikh F, Wu AJ, et al. Stereotactic body radiation therapy (SBRT) improves local control and overall survival compared to conventionally fractionated radiation for stage I non-small cell lung cancer (NSCLC). Acta Oncol 2018;57:1567-73.

95. Baker S, Sharma A, Peric R, et al. Prediction of early mortality following stereotactic body radiotherapy for peripheral early-stage lung cancer. Acta Oncol 2019;58:237-42.

96. Nicosia L, Reverberi C, Agolli L, et al. Long term results of single high dose Stereotactic Body Radiotherapy in the treatment of primary lung tumors. Sci Rep 2019;9:15498.

97. Schonewolf CA, Heskel M, Doucette A, et al. Five-year Long-term Outcomes of Stereotactic Body Radiation Therapy for Operable Versus Medically Inoperable Stage I Non-small-cell Lung Cancer: Analysis by Operability, Fractionation Regimen, Tumor Size, and Tumor Location. Clin Lung Cancer 2019;20:e63-71.

98. Kwak YK, Park HH, Choi KH, et al. SUVmax Predicts Disease Progression after Stereotactic Ablative Radiotherapy in Stage I Non-small Cell Lung Cancer. Cancer Res Treat 2020;52:85-97.

99. Mayne NR, Lin BK, Darling AJ, et al. Stereotactic Body Radiotherapy Versus Delayed Surgery for Early-stage Non-small-cell Lung Cancer. Ann Surg 2020;272:925-9.

100. Chi A, Wen S, Liao Z, et al. What would be the most appropriate $\alpha / \beta$ ratio in the setting of stereotactic body radiation therapy for early stage non-small cell lung cancer. Biomed Res Int 2013;2013:391021.

101. Duval S, Tweedie R. Trim and fill: A simple funnel-plotbased method of testing and adjusting for publication bias in meta-analysis. Biometrics 2000;56:455-63.

102. Belfiore G, Moggio G, Tedeschi E, et al. CT-guided radiofrequency ablation: a potential complementary therapy for patients with unresectable primary lung cancer-a preliminary report of 33 patients. AJR Am J Roentgenol 2004;183:1003-11.
103.Pennathur A, Luketich JD, Abbas G, et al. Radiofrequency ablation for the treatment of stage I non-small cell lung cancer in high-risk patients. J Thorac Cardiovasc Surg 2007;134:857-64.

104. Okuma T, Matsuoka T, Yamamoto A, et al. Determinants of local progression after computed tomography-guided percutaneous radiofrequency ablation for unresectable lung tumors: 9-year experience in a single institution. Cardiovasc Intervent Radiol 2010;33:787-93.

105.Ambrogi MC, Fanucchi O, Cioni R, et al. Long-term results of radiofrequency ablation treatment of stage I non-small cell lung cancer: a prospective intention-to-treat study. J Thorac Oncol 2011;6:2044-51.

106.Hess A, Palussière J, Goyers JF, et al. Pulmonary radiofrequency ablation in patients with a single lung: feasibility, efficacy, and tolerance. Radiology 2011;258:635-42.

107. Hiraki T, Gobara H, Mimura H, et al. Percutaneous radiofrequency ablation of clinical stage I non-small cell lung cancer. J Thorac Cardiovasc Surg 2011;142:24-30.

108. Lee H, Jin GY, Han YM, et al. Comparison of survival rate in primary non-small-cell lung cancer among elderly patients treated with radiofrequency ablation, surgery, or chemotherapy. Cardiovasc Intervent Radiol 2012;35:343-50.

109. Sofocleous CT, May B, Petre EN, et al. Pulmonary thermal ablation in patients with prior pneumonectomy. AJR Am J Roentgenol 2011;196:W606-12.

110. Kim SR, Han HJ, Park SJ, et al. Comparison between surgery and radiofrequency ablation for stage I non-small cell lung cancer. Eur J Radiol 2012;81:395-9.

111.Lanuti M, Sharma A, Willers H, et al. Radiofrequency ablation for stage I non-small cell lung cancer: management of locoregional recurrence. Ann Thorac Surg 2012;93:921-7; discussion 927-88.

112. Ridge CA, Silk M, Petre EN, et al. Radiofrequency ablation of T1 lung carcinoma: comparison of outcomes for first primary, metachronous, and synchronous lung tumors. J Vasc Interv Radiol 2014;25:989-96.

113. Ambrogi MC, Fanucchi O, Dini P, et al. Wedge resection and radiofrequency ablation for stage I nonsmall cell lung cancer. Eur Respir J 2015;45:1089-97.

114. Lam A, Yoshida EJ, Bui K, et al. Patient and Facility Demographics Related Outcomes in Early-Stage NonSmall Cell Lung Cancer Treated with Radiofrequency Ablation: A National Cancer Database Analysis. J Vasc Interv Radiol 2018;29:1535-1541.e2.

115. Bilal H, Mahmood S, Rajashanker B, et al. Is 
radiofrequency ablation more effective than stereotactic ablative radiotherapy in patients with early stage medically inoperable non-small cell lung cancer? Interact Cardiovasc Thorac Surg 2012;15:258-65.

116. Timmerman R, Galvin J, Michalski J, et al. Accreditation and quality assurance for Radiation Therapy Oncology Group: Multicenter clinical trials using Stereotactic Body Radiation Therapy in lung cancer. Acta Oncol 2006;45:779-86.

117. Murray P, Franks K, Hanna GG. A systematic review of outcomes following stereotactic ablative radiotherapy in the treatment of early-stage primary lung cancer. Br J Radiol 2017;90:20160732.

118. Sharabi AB, Lim M, DeWeese TL, et al. Radiation and checkpoint blockade immunotherapy: radiosensitisation and potential mechanisms of synergy. Lancet Oncol 2015;16:e498-509.

119. Reits EA, Hodge JW, Herberts CA, et al. Radiation modulates the peptide repertoire, enhances MHC class I expression, and induces successful antitumor immunotherapy. J Exp Med 2006;203:1259-71.

120. Chakraborty M, Abrams SI, Camphausen K, et al. Irradiation of tumor cells up-regulates Fas and enhances CTL lytic activity and CTL adoptive immunotherapy. J Immunol 2003;170:6338-47.

121. Formenti SC, Demaria S. Systemic effects of local radiotherapy. Lancet Oncol 2009;10:718-26.

122. Rapoport BL, Anderson R. Realizing the Clinical Potential of Immunogenic Cell Death in Cancer Chemotherapy and Radiotherapy. Int J Mol Sci 2019;20:959.

123. Weichselbaum RR, Liang H, Deng L, et al. Radiotherapy and immunotherapy: a beneficial liaison? Nat Rev Clin Oncol 2017;14:365-79.

124.Jarosz-Biej M, Smolarczyk R, Cichoń T, et al. Tumor Microenvironment as A "Game Changer" in Cancer Radiotherapy. Int J Mol Sci 2019;20:3212.

125.Dewan MZ, Galloway AE, Kawashima N, et al. Fractionated but not single-dose radiotherapy induces an immune-mediated abscopal effect when combined with anti-CTLA-4 antibody. Clin Cancer Res 2009;15:5379-88.

126. Formenti SC, Demaria S. Radiation therapy to convert the tumor into an in situ vaccine. Int J Radiat Oncol Biol Phys 2012;84:879-80.

127.Luke JJ, Lemons JM, Karrison TG, et al. Safety and Clinical Activity of Pembrolizumab and Multisite Stereotactic Body Radiotherapy in Patients With Advanced Solid Tumors. J Clin Oncol 2018;36:1611-8.

128. Reynders K, Illidge T, Siva S, et al. The abscopal effect of local radiotherapy: using immunotherapy to make a rare event clinically relevant. Cancer Treat Rev 2015;41:503-10.

129. Fietta AM, Morosini M, Passadore I, et al. Systemic inflammatory response and downmodulation of peripheral CD25+Foxp3+T-regulatory cells in patients undergoing radiofrequency thermal ablation for lung cancer. Hum Immunol 2009;70:477-86.

130. Ghanamah M, Berber E, Siperstein A. Pattern of carcinoembryonic antigen drop after laparoscopic radiofrequency ablation of liver metastasis from colorectal carcinoma. Cancer 2006;107:149-53.

131. Schneider T, Hoffmann H, Dienemann H, et al. Immune Response After Radiofrequency Ablation and Surgical Resection in Nonsmall Cell Lung Cancer. Semin Thorac Cardiovasc Surg 2016;28:585-92.

132.Ito F, Vardam TD, Appenheimer MM, et al. In situ thermal ablation augments antitumor efficacy of adoptive T cell therapy. Int J Hyperthermia 2019;36:22-36.

133. Shaobin W, Yu X, Jiatian L, et al. Changes of CD4+ T-cell subsets after radiofrequency ablation in lung cancer and its significance. J Cancer Res Ther 2016;12:C166-70.

134. Theelen WSME, Peulen HMU, Lalezari F, et al. Effect of Pembrolizumab After Stereotactic Body Radiotherapy vs Pembrolizumab Alone on Tumor Response in Patients With Advanced Non-Small Cell Lung Cancer: Results of the PEMBRO-RT Phase 2 Randomized Clinical Trial. JAMA Oncol 2019;5:1276-82.

135. Shi L, Chen L, Wu C, et al. PD-1 Blockade Boosts Radiofrequency Ablation-Elicited Adaptive Immune Responses against Tumor. Clin Cancer Res 2016;22:1173-84.

136. den Brok MH, Sutmuller RP, van der Voort R, et al. In situ tumor ablation creates an antigen source for the generation of antitumor immunity. Cancer Res 2004;64:4024-9.

137. Tong Y, Yang H, Xu X, et al. Effect of a hypoxic microenvironment after radiofrequency ablation on residual hepatocellular cell migration and invasion. Cancer Sci 2017;108:753-62.

138. Erinjeri JP, Thomas CT, Samoilia A, et al. Image-guided thermal ablation of tumors increases the plasma level of interleukin-6 and interleukin-10. J Vasc Interv Radiol 2013;24:1105-12.

139. Shi L, Wang J, Ding N, et al. Inflammation induced by incomplete radiofrequency ablation accelerates tumor progression and hinders PD-1 immunotherapy. Nat Commun 2019;10:5421.

140.Stroup DF, Berlin JA, Morton SC, et al. Meta-analysis of observational studies in epidemiology: a proposal for 
reporting. Meta-analysis Of Observational Studies in Epidemiology (MOOSE) group. JAMA 2000;283:2008-12.

141.Fu Y, Xi M, Pan Y, et al. Stereotactic Body Radiotherapy as a Salvage Therapy after Incomplete Radiofrequency Ablation for Hepatocellular Carcinoma: A Retrospective Cohort Study. J Oncol 2020;2020:4835653.

142. Steber CR, Hughes RT, Urbanic J, et al. Long-
Term Outcomes From a Phase 2 Trial of Radiofrequency Ablation Combined With External Beam Radiation Therapy for Patients With Inoperable Non-Small Cell Lung Cancer. Int J Radiat Oncol Biol Phys 2021;111:152-6.

(English Language Editor: J. Reylonds)
Cite this article as: Zhang $\mathrm{R}$, Kang $\mathrm{J}$, Ren S, Xing L, $\mathrm{Xu}$ Y. Comparison of stereotactic body radiotherapy and radiofrequency ablation for early-stage non-small cell lung cancer: a systematic review and meta-analysis. Ann Transl Med 2022;10(2):104. doi: 10.21037/atm-21-6256 
Supplementary

Table S1 Egger's test results for publication bias

\begin{tabular}{|c|c|c|c|c|c|c|}
\hline \multirow{2}{*}{ Year } & \multicolumn{4}{|c|}{ LC } & \multicolumn{2}{|c|}{ OS } \\
\hline & $P$ value & $P$ value after TFA & $P$ value & $P$ value after TFA & $\begin{array}{c}\text { SBRT } \\
\text { P value }\end{array}$ & $\begin{array}{c}\text { RFA } \\
\text { P value }\end{array}$ \\
\hline 1 & 0.001 & 0.148 & 0.024 & 0.104 & 0.767 & 0.835 \\
\hline 2 & 0.001 & 0.069 & 0.332 & & 0.767 & 0.116 \\
\hline 5 & 0.011 & 0.061 & 0.999 & & 0.428 & 0.618 \\
\hline
\end{tabular}

SBRT, stereotactic body radiation therapy; RFA, radiofrequency ablation; Cl, confidence interval; OS, overall survival; TFA, trim-and-fill analysis. 